\title{
The Grenadian Crisis and the Caribbean Left
}

\author{
Clive Y. Thomas
}

The Grenadian revolution has been widely canvassed as the most important achievement of the left in the English-speaking Caribbean. Regionally, its importance has been dwarfed only by the Cuban revolution and the Sandinistas' struggles in Nicaragua. It is therefore of great importance to analyse the impact of its collapse in October 1983 on the 'popular forces' of the English-speaking Caribbean. By 'popular forces' I refer to the broad constituency of people who are opposed to colonisation and neo-colonial forms of metropolitan domination of the region; to its involvement in international rivalries; to the perpetuation of poverty and vast domestic inequalities in the distribution of income, wealth, jobs and power; and to the systematic suppression of human rights and the effective exclusion of the broad masses of the region's population from the major say in the governance of their lives. Some of this constituency is organised into left-wing political parties, but by no means all of it is, and it is compatible with a multiplicity of party organisations.

To evaluate the events in Grenada from this perspective it is useful to distinguish between the execution and assassination of Bishop, his allies in the government and others, and the invasion by the Organisation of the Eastern Caribbean States (OECS) and the USA. While these two aspects are closely linked, the former set of events is unique in our historical experience, whereas US invasion (albeit this time in alliance with the OECS states) is commonplace. It is said that US administrations have ordered the invasion of other countries more than 100 times in the past 100 years, and in the Western hemisphere alone it has done so more than 60 times this century. Given the frequency of these invasions, we should perhaps have come to expect them, even if we do not accept them! What we certainly have not come to expect, and hopefully will never accept, is that the execution of Bishop and his colleagues belongs to any tradition of any section of the popular forces of the region. To anticipate the analysis which follows, I would venture to say that had the invasion not occurred, the Grenadian revolution
- with all its positive gains - had self-destructed with the execution of Bishop, and because of this, would have had no continued legitimacy among the broad mass of the Caribbean peoples. In a perverse way, because the invasion took place after the revolution had already destroyed itself, it resulted in breathing new life into the corpse.

\section{The Paralysis of Regional Integration}

It is useful to begin by recalling the main lines of development of the regional integration movement just prior to these events, using these as an index of regional political consciousness.

i) After a long period of dormancy, when the highest decision-making authority of the regional integration movement, the Caribbean Community (CARICOM) Heads of Government Conference, could not be convened, two Heads of Government Conferences were held in a period of eight months, in November 1982 and June 1983. Following these meetings the pronouncements made by the various governments were very optimistic about the future of the regional movement. These included Grenada, whose full incorporation into the CARICOM fold then seemed beyond question.

ii) The concerns of the smaller states of CARICOM, which had always plagued the integration movement, were placed high on the regional agenda, and the institutionalisation of the grouping into the OECS in 1981 marked a major advance in addressing the plight of the small states. Grenada had played a leading part in this development - once again confirming the increasing acceptance of their revolutionary process into the regional outlook.

iii) While the impact of national and international developments was taking a severe toll on the economic arrangements of CARICOM in several areas - e.g. the collapse of the regional currency settlement and clearing facility (CMCF), the rise in protectionism and a growing tendency towards intraregional trade and

IDS Bulletin, 1985, vol 16 no 2, Institute of Development Studies, Sussex 
exchange rate conflicts - at a regional level adherence to strategies of greater local and regional control of resources, decision-making in economic affairs, technology, skills and so on was growing. This development was accompanied by many public pronouncements of an anti-imperialist nature by governments, as well as by trade unions, churches, and human rights and social organisations. Examples of these are pointedly sceptical remarks about, and criticisms of, the Caribbean Basin Initiative (CBI), and its hidden designs aimed at 're-colonisation of the region'; strongly critical statements about the European Community and its handling of the EECACP economic arrangements; and forceful support in international fora for a New International Economic Order (NIEO), along with calls for greater SouthSouth cooperation as a counter to domination by the North. These attitudes were also reflected in a more favourable disposition by all the major institutions of the popular forces towards the non-aligned movement.

iv) In the field of international relations (and of the greatest political significance regionally) the idea that the Caribbean should be declared a 'zone of peace' gained wider acceptance. While the Caribbean Conference of Churches had played a leading role in the development of this idea, many other nongovernmental organisations and some governments and ruling parties had also declared their adherence to it. In the context of escalated US warfare in the region and the Reagan administration's aggressive reassertion of a 'right' to dictate the political complexions of governments 'in its own backyard', this marked the development of an important antiimperialist consensus.

v) Within the region generally, and particularly at governmental levels, there was a concerted move towards an acceptance of 'political pluralism' as a feature of the integration movement. While important sections of the popular forces wanted this linked to an insistence on minimal standards of political culture, such as representative governments, and a positive environment for the development of human rights, both Burnham's brand of dictatorship (which he called 'socialism' in Guyana, but which they considered repugnant) and the Grenadian revolutionary process were accepted as being the internal concerns' of the countries themselves, and not an issue to be deliberated upon by a regional intergovernmental organisation. (This also represented a reversal of the initial inability of heads of government to accept the overthrow of Gairy, which had been one of the factors that had for a long time prevented the convening of the Heads of Government Conference.)

While these developments were certainly uneven both among and within the territories concerned, there can be little doubt that a progressive, liberal, anti- imperialist and nationalist consciousness had come to constitute the hegemonic tendency in regional opinion. This did not, of course, take place overnight. It was the end result of a long series of conflicts between the popular forces and the colonial consciousness which had been built up within the region through centuries of colonial domination; and later, after World War II, between the ideas of the popular forces and the hysterical anti-communist, anti-socialist, and anti-Cuban opinion emanating, in particular, from the ruling circles of the USA - ideas which the dominant classes in the Caribbean sought to establish in place of the colonial outlook. Naturally, the success of the nationalist-progressive ideas depended upon, and in turn supported, the increasingly favourable national, regional and international context of working-class and peasant struggles after World War II, and the growth of indigenously educated classes which followed the establishment of a local and regional higher education system.

My first major proposition is, then, that the trauma of the executions in Grenada, as a method of settlement of political issues on the left, shattered the advantageous position held by the body of opinion, theories and ideas which support the interests of the popular forces in the Caribbean. This defeat was critical, for without the growth and consolidation of the hegemonic position of progressive/liberal/nationalist opinion in the region, the organisational and ideological growth of the left will always be stunted. Without this regional consciousness, the mass of the population becomes easy prey to the appeal of the basest aspects of the ideologies of the ruling classes in the metropole (given the social, cultural, communication and other forms of metropolitan domination of the area). This destruction of the hegemony of the ideology of the popular forces was not due to the invasion but to the imploding of the revolutionary process. Indeed, one has only to envisage an invasion in another context (i.e. Bishop alive) to be able to imagine how different the effects on the position of the ideas of the popular forces would have been (it is some measure of this that despite threats, no invasion was attempted before Bishop's death).

Several bits of evidence can be pointed to in support of this judgement:

i) The growing acceptance of the notion of political pluralism referred to earlier has been replaced by a polarisation of ideologies in the region: pro-colonial sentiments have risen to the fore and now dominate the media. Many advocates of pro-colonial views, who had been silenced by the weight of the prevailing regional opinion, have emerged emboldened by the atrocities of the Grenadian left and the public outrage 
against them. Examples include the summary expulsion from Barbados of Ricky Singh, editor of Caribbean Contact, easily the most important and widely circulated publication in the region. Published by the Caribbean Conference of Churches, it had condemned the Grenadian executions forthrightly, but had also convincingly opposed the invasion by the US and the OECS, exposing in its reportage much of the disinformation employed by the invaders at the time. There is also Seaga's call for the exclusion of Guyana (which had opposed the invasion) from CARICOM on human rights grounds, while at the same time suggesting the incorporation of Haiti and the Dominican Republic into a CARICOM II. We might also cite the move by the government of St. Christopher-Nevis, in the aftermath of the invasion, to give citizenship to 'substantial investors' in that country, whether or not the persons concerned had ever lived in or visited the territory!

ii) The 'zone of peace' position, which had gained considerable acceptance, was replaced by Cold War exchanges, reinforcing the polarisation of ideological positions and weakening acceptance of the principle of political pluralism in the regional system. Thus the invaders claimed that they had "eliminated the Marxist-Leninist axis of conspiracy and violence in the region'. In turn this provoked calls for the left to 'stop being naive' and forge close links to the 'presumed axis' since without these, no progressive, nationalist development within the region would be possible. The invaders backed up their statements by moves to increase their military capabilities substantially under US guidance, and to use their special connections with the US government since the invasion openly as a basis for 'stabilising' the existing order in the region. That their position was a popular one cannot be denied, since the wave of snap elections in OECS states in the wake of the invasion led to the return of the incumbent administrations with enlarged majorities. ${ }^{1}$

iii) Instead of the increasing assertion of national consciousness and opposition to metropolitan domination, those who presumably hold political power have reduced the region, and CARICOM in particular, to a position where the major axis revolves around the stances taken on the invasion. In some quarters, e.g. Trinidad-Tobago (which opposed the invasion and whose government justifiably feels that it was deceived and manipulated over it), this has bred a certain 'inwardness' in attitudes at all levels of the society - a factor which was instrumental in the demise of the earlier West Indies Federation.

\footnotetext{
In the case of Jamaica's Seaga, who has strongly identified his administration with Reagan's ideology, the snap election produced a 'one-party state': Michael Manley's PNP boycotted the elections because known irregularities in the voters' list had not been attended to, despite the existence of an agreement with the government that they would be before any elections were held.
}

iv) Finally, it is clear that the US has effectively filled whatever power vacuum had existed in the region. Despite the propaganda of conservatives, neither Cuba, nor the Soviet Union, nor any of their alleged proxies had come anywhere near to filling the power vacuum which was created by the removal of Britain as the colonial power. The final seal was put on US ascendancy at the Commonwealth Heads of Government Conference held in India in November 1983, where the conference communique in relation to the Caribbean declared that 'the emphasis should now be on reconstruction, not recrimination'. This formulation clearly put the US action 'above the law', as even governments opposed to the invasion thus effectively adjured their responsibility to resist the violation of international law involved. The emphasis was only on 'repairing the damage'. Such a development would not have been possible if the invasion had not taken place in the context of a revolutionary process which had already destroyed itself.

\section{The Abandonment of Constitutionality}

The self-destruction of the revolutionary process in Grenada also bears directly on the organisation and future development of popular political formations in the region. First, the events which led up to the execution of Maurice Bishop and others clearly indicate the importance which must be attached to constitutionality, legality, and due process, in the legitimation of political action within the region. The success of the New Jewel Movement and the Maurice Bishop Government in gathering support to overthrow the Gairy regime, and subsequently in winning the support of most West Indians for the Grenadian revolutionary process, rested largely on their systematic exposure, when in opposition, of Gairy's methods of dictatorial rule and his gross violations of regionally accepted norms of constitutionality, legality, and due process. Conversely, their own subsequent failure to hold free and fair elections tarnished their own reputation in the eyes of large sections of the popular forces. This was particularly so because immediately after the successful overthrow of Gairy, a pledge was made to hold 'free and fair elections, and elections free from fear', to uphold due process and to protect the human rights which Gairy had so grossly violated. The hands of critics were stayed by fear of splitting ranks in the face of threats of imminent invasion by the USA, as well as by what appeared - to sympathetic outsiders at least - to be serious efforts on the part of the New Jewel Movement to develop alternative forms of so-called direct democracy.

The betrayal of trust implicit in the murderous way in which the political struggles in the New Jewel Movement finally resolved themselves in October 
1983 has been particularly traumatic for those sections of the popular forces, which in the interest of solidarity had refrained from open criticism. The immediate consequence of this (and hopefully it will be an everlasting one) is that no regime, no matter how popular it may initially be, will be able to sustain the support of the popular forces of the region if its political rule is not grounded in constitutionality, legality and due legal process. This lesson can be a lasting gain for the West Indian peoples. The only regret is that the price paid for learning it should have been so high.

To oversimplify a complex issue in terms of a general proposition: after Grenada no social project carried out in the name of the masses of the Caribbean peoples, whether by government or opposition, will receive widespread support from the popular forces and their organisations if it does not clearly embrace political democracy as its norm of political conduct. Whatever difficulties may exist in interpreting this, it cannot mean less than i) the absence of legal and/or administrative discrimination on the grounds of race, religion, tribe, property/income, political party affiliation, affecting the expression of political opinion either directly or through elected representatives; ii) no restrictions apart from age, on the practice of one person to vote; iii) equality in the legal status of all political parties, to ensure that contest between organised political groups is a real contest, representing real alternatives; iv) the principles of majority rule in the election of representatives and in the legislative process - with the proviso that this does not limit the minority's freedom to become a legal and constitutional majority; v) due process in the legal system, to ensure that the above rights are enforceable.

The denial of these rights in Grenada was the more damaging given certain elements in the region's history. In the English-speaking Caribbean, the struggles against slavery, indentured servitude and colonial bondage had more frequently than not taken on a legal and constitutional form. Thus the struggle against servitude was often expressed as a struggle for the right to personal liberty guaranteed and protected by law. Similarly the struggles against colonial bondage and its particular forms of economic domination were often expressed as a struggle for such rights as self-determination, one person one vote, independent trade unionism and so forth. There is therefore a deeply embedded tradition which views constitutional and socioeconomic issues as inseparable. This is not simply the product of 'colonial propaganda about the virtues of Westminster parliamentarianism', as some would glibly dismiss it, but reflects a deep recognition on the part of the popular forces that the prevailing levels of constitutionality, representative government, legality, due process and so on are the product of successful struggles waged both under colonialism and since independence, not 'gifts' of the colonial authorities, or of the later post-colonial ones. Additionally, we might further note that the prevailing norms of political behaviour directly affect the institutional forms and organisational procedures of the popular forces, and so will always bear directly on their struggles for social advances. To ignore these truths is to imperil the mass movement in the region, and thus the long-term project of creating an egalitarian, democratic and socialist society.

From a more general standpoint, one of the most commonplace observations made by political scientists of various persuasions about the independence settlements after World War II is that except where these were preceded by 'wars of national liberation' which resulted in an effective 'smashing of the colonial state structures' the transfer of power from coloniser to colonised was based on the exclusion of the masses, and in particular working-class organisations, from state power. Within the Caribbean region the truth of this observation is seen most clearly in the successful exclusion of the Peoples Progressive Party (PPP) from effective state power in Guyana from 1953 onwards. In 1953 the PPP was probably the most advanced working class political organisation in the region, if not in the British Empire, and bore the distinction of being the first freely elected Marxist government in that empire (and indeed in this hemisphere). The classes to whom the colonising power instead handed over state power have not unnaturally sought to perpetuate, through whatever means possible, the systematic exclusion of the masses from authentic power.

It is this negation of their democratic rights which determines much of the popular forces of opposition to the existing political order. Consequently, any political process which reproduces this exclusion cannot enjoy popular respect; and so the naive vanguardism and 'left-wing' authoritarianism of the New Jewel Movement prior to Bishop's overthrow opened the way to a renewed depoliticisation of the peoples of the region.

Here we had, in effect, a political party of less than 100 members (including candidate members and applicant members) discussing the future of Grenadian society (which despite its small size was exceedingly complex) as if the important decisions to be made were their sole prerogative. Worse still, regardless of where the debates took place in the party, effective power lay in the hands of the 'majority' in the much smaller political bureau. When the masses intervened against Bishop's detention and freed him, the same vanguardism inexorably led this 'majority' to summarily execute the head of the government, leader 
of the revolutionary process, and commander-in-chief without any pretence whatsoever of due process. In retrospect this development might well have been a foregone conclusion from the moment that Bishop was put under house arrest on the basis of a 'decision' of a political bureau acting as if its decisions automatically became law. Is it any wonder that many rightly asked: if the party could treat its own in such a manner, what then was the position of all those who did not belong to the chosen 100 ? The savagery and contempt for life displayed in these actions will live on and be pointed to time and again in the region as the particular 'lunacy of the left'. The deserved distrust which this has generated will for a long time limit the incorporation of socialist ideology into the struggles of the popular forces throughout the region.

\section{The Responsibility of the Intellectuals}

My third proposition refers to the 'organic intellectuals' of the Caribbean who contributed so much to undermining the previous hegemony of colonial and metropolitian ideas in the region. For them as a group important lessons can be drawn from the Grenadian tragedy. Many of these progressive intellectuals, (like their counterparts in Western Europe and North America), have been demonstrably uncritical of political processes initiated in the name of the 'left', operating as 'cheerleaders' applauding the actions of those responsible, rather than as constructive and creative critics. While this is seen as 'giving solidarity', in reality it indicates an important weakness.

The weakness consists in failing to grasp intellectually and in practice the distinction between recognising a process of social development which is objectively progressive, and giving uncritical political support to the class or group which is in control of state power at the time this takes place. Marx faced this issue squarely when he acknowledged in the fullest manner the objective progressiveness of the bourgeois class in breaking the fetters of feudal domination. This did not, however, lead him to support politically the project of the bourgeoisie. This he saw as the substitution of another form of domination, albeit at a higher level of human achievement. By contrast, in the Third World and elsewhere we find intellectuals identifying objective social advances, such as the spread of political independence, the subsequent nationalisation of natural resources, and so on, but then accepting these as sufficient grounds for giving unquestioning political support to the political groups controlling state power when these developments are achieved. Loyalty to the regime in power is substituted for a constructively critical attitude. In this substitution, intellectuals as a group negate what is to my mind their single most important social attribute, namely capacity for creativity and the exercise of independent critical power. One can understand the temptations which give rise to this attitude: fear of giving ammunition to the imperialist enemy; the need to maintain morale among the revolutionary leaders; the fear of creating doubts about one's own revolutionary credentials. Succumbing to these temptations, however, as occurred in the case of Grenada, does not serve the long-term project of social transformation and an end to all forms of exploitation. Those who hold state power sense this weakness, and it adds to the corruptibility inherent in all situations where too much power is concentrated in the hands of too few persons.

In retrospect, events in Grenada show that there is an urgent need for a serious process of self-criticism among intellectuals who side with the popular forces. Many examples of what I refer to can be found in our failure to respond to major issues generated by the Grenadian revolutionary process. For instance, did the geopolitical realities which must be taken into account by the revolutionary process in a micro-state located in the strategic back yard of the USA permit the playing of a leading rhetorical role in the global ideological struggles between imperialism and socialism? To what extent does such rhetoric unnecessarily raise the profile of the micro-state, and in so doing increase the dangers of directly embroiling it in the heightened overt and covert hostilities of the two major military blocs? Does the same consideration arise when the small state is under conservative political control, as in the case of Jamaica, where Seaga plays a leading role in the global ideological debates between imperialism and socialism? Or is it simply, as some argue (after Grenada), that there is no political or national 'space' available to a small state in the highly polarised international arena of today, which will allow it to operate independently, when it is bent on a process of radical transformation? To what extent must such issues affect the search for consensus among the popular forces?

Similar fundamental issues not faced by left intellectuals include the question of what problems are created when political rhetoric, and strong foreign policy positions on matters of global significance to the major powers, outstrip the internal economic transformation of the country; whether the power vacuum created by the departure of the British could have been filled in ways which did not require the ascendancy of one of the two major military blocs in the region; or whether the Grenadian experiments with direct democracy could have constituted an authentic alternative to representative democracy.

Issues such as these had to be confronted daily during the existence of the Grenadian revolutionary process. Yet, apart from the last of them (where in any case 
disputes were in whispered tones and the issues were only raised obliquely) little real debate took place and little creativity was evidenced. It is therefore not so surprising that those at the centre of political events so easily accepted the profoundly anti-democratic theses advanced during the inter-party disputes which immediately preceded the tragedy of October 1983. No one challenged the implicit assumption of the leading protagonists in the dispute that if the majority of the party's leadership moved to a 'scientific' embrace of Marxist-Leninist ideology, the time was ipso facto ripe for a Leninist or Soviet-type model of social transformation. The rich regional history of inner-party struggles, such as those of the People's National Party of Jamaica, or the PPP of Guyana during the 1940 s and 1950 s, was never once referred to in the course of these developments. Instead there was the arrogance of raising a political theory to a level of a truth above the wishes of the masses.

\section{Conclusion}

It is for these reasons that I have advanced the argument that the events preceding the invasion of
Grenada, as revealed in the distintegration of the New Jewel Movement and the imploding of the revolutionary process, have a significance for the popular forces and left political organisations in the region, which can hardly be underestimated. Indeed, the issues raised by these events have a wider significance than for the Caribbean alone. Wherever people seek to create a new social order and are not prepared to build on the achievements of the old, they are bound to confound their own efforts and produce tragedies such as those we have witnessed in Grenada.

\author{
Bibliography \\ Latin American Bureau, 1984, Grenada - Whose Freedom?, \\ London \\ O'Shaughnessy, H., 1984, Grenada-Revolution, Invasion and \\ Aftermath, Hamish Hamilton, London \\ Thomas, Clive Y., 1984, The Rise of the Authoritarian State in \\ Peripheral Societies, Monthly Review Press, New York
}

